\title{
BUTTERFLY DIVERSITY IN MULSHI, DISTRICT PUNE (MS) INDIA
}

\author{
Hemalata Karkar \\ Mahatma Phule Mahavidyalaya,Pimpri, Pune-17. \\ Corresponding Author: drhskarkar7113@gmail.com
}

Communicated: 19.07.2020
Revision :23.07.20 \& 15.08.20
Accepted: 27.08 .2020
Published: 30.09 .2020

\begin{abstract}
:
The present study was carried out at Mulshi Tahsil of Pune District, Maharashtra, India, during August 2013 to August 2019. A total of 27 species of butterflies belonging to 24 genera under five families were recorded from Mulshi Tahsil. Out of 21 species, 10 species of butterflies are scheduled species. Family Nymphalidae is dominating in study area, followed by Lycaenidae, Hesperiidae, Pieridae, and Papilionidae. The seasonal pattern in the abundance of butterflies, their biotopes and nectar food plants were also studied. Mud-puddling is also observed among some butterflies. Forest biotope is found to be rich for butterfly species. Thirty-two nectar food plants were identified belonging to 15 plant families. Plants of family Asteraceae were found to be preferred by Butterflies as nectar food plants. Visits of Butterflies were more frequent to flowers with tubular corollas than to non-tubular ones, to yellow coloured flowers and to flowers with a bloom for longer period in the year. Highest species abundance was observed in the months during August to November. A decline in species abundance was observed from the months of December to January and continued up to the end of May. These findings are important with respect to monitor butterfly and plant diversity and to define conservation strategies in the Mulshi Tahsil.
\end{abstract}

Key words: - Butterfly diversity, food plants, seasonal abundance, biotopes, Mulshi Tahsil.No of words: 221.

\section{INTRODUCTION:}

Butterflies are scaled wing insects belonging to order Lepidoptera of class Insecta. Butterflies are an integral part of the forest ecosystem. They show distinct patterns of habitat utilization. Being highly sensitive to changes in the environment, they are easily affected by even relatively minor perturbations in the habitat, so much so that, they have been considered as indicators of environment quality and health of an ecosystem ${ }^{1}$ (Rosenberg et al., 1986). Feeding is a significant activity and food may be often the most decisive factor affecting distribution, abundance and movements of animals. In Butterflies, this has a special relevance because food and mode of feeding are different in the larval and adult stages ${ }^{2}$ (Kunte, 1997). Butterflies and their caterpillars are dependent on specific host plants for foliage, nectar and pollen as their food. Thus, Butterfly diversity reflects overall plant diversity, especially, that of the herbs and shrubs, in the given area. The herbs and shrubs start their life cycle in the beginning of the Monsoon and complete it by the end of post-monsoon season. While some shrub like Lantana camara shows flowering throughout the year. The increased industrialization and urbanization of Pune has affected the ecology of this important industrial District in the Maharashtra, India. Four tropical habitats in North-Western Ghats. These four sites were close to Pune city within a radius of 20km. 3Rane and Ranade (2004) studied Butterflies of Tamhini-Dongarwadi area, Mulshi, Maharashtra. "Padhye et al., (2006) studied season and landscape wise distribution of Butterflies in Tamhini, Northern Western Ghats of India. Sharma (2009) studied the fauna of Bhimashankar Wildlife Sanctuary, Maharashtra. ${ }^{5}$ Chandekar et al., (2014) studied the seasonal patterns in the abundance of butterflies, their biotopes and nectar food plants from Maval Tahsil, Pune District, Maharashtra, India. 
Mulshi Tahsil was selected for present study of butterfly diversity with respect to seasonal abundance, biotopes and nectar food plants in Mulshi. The diversity studies are important for environmental protection.

\section{MATERIAL \& METHODS:}

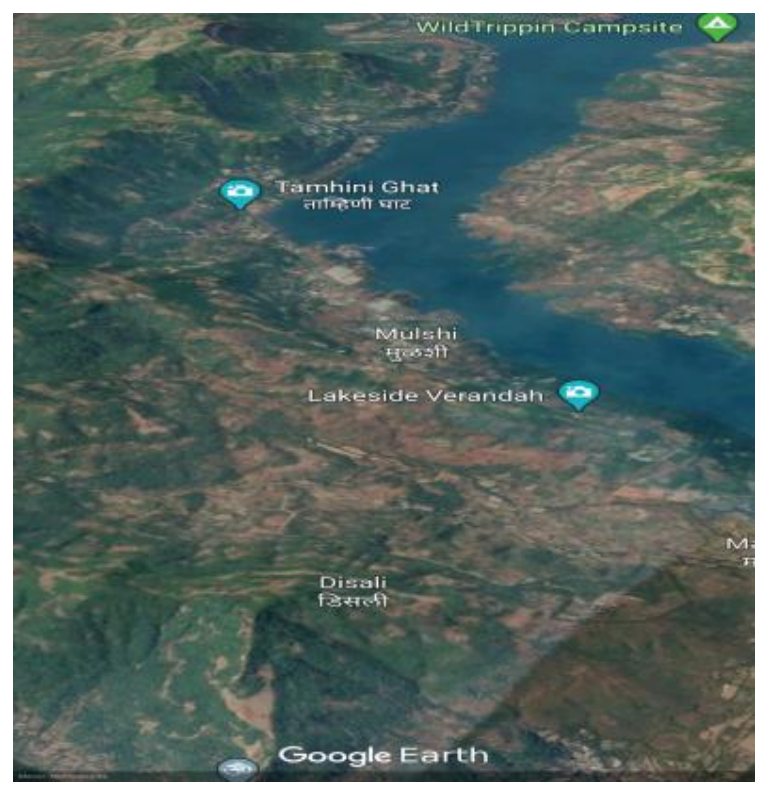

\section{Google maps}

\section{The Study Area:}

Tahsil Mulshi with head quarter Paud is located $42 \mathrm{Km}$ from Pune towards west direction. It is situated at $18^{\circ} .32^{\prime}$ North latitude $\& 73^{\circ} .37^{\prime}$ East longitude, altitude is about 576 meters. This Tahsil area is also irregular in shape, having an area of 1039 sq. km., bordered by Tahsil Haveli in the east, Tahsil Velhe in south, Tahsil Maval towards the north and district Raigad in west. This area receives heavy rainfall. Most of the area is covered with forest. Sag, Teak, Oak, Mango, are the trees found in the forest. Paddy fields are grown on large scale in this region. River Mula flows through this area. Mulshi dam located here is power generating station. The study area was fully explored during August 2013 to August 2019. To study the seasonal patterns and diversity in butterfly abundance in relation to nectar food plants, the entire year divided into three seasons i.e. pre-Monsoon (February to May), Monsoon (June to September) and Post-Monsoon (October to January). The study area was visited twice in each season during the study period. In the said investigation the selected sites were surveyed mainly between 7.00 am to $1.00 \mathrm{pm}$. Butterfly species were identified directly in the field visually with the help of field guides followed by photography, in difficult cases, rarely by capture. Collection was restricted to those specimens that could not be identified directly. All scientific names and common English names were designated as per Varshney (1983). Classification of Butterflies is after Gaonkar (1996). Benthum \& Hooker (1862-1863) system of classification is followed for plants. Statistical analysis of the data was carried out using Ecological Analysis Package- Biodiversity Pro. During field work from study area, hygrometer was used to keep record of humidity and temperature. Global Positioning System (GPS) instrument was used to record latitude, longitude and altitude.

Camera: Sony Camera Model No. DSLR, 14 Mega Pixels

Hygrometer: Hi-Tech Temperature Clock / Humidity HTC-1

Global Positioning System (GPS) Instrument: GPS MAP 60 CSX

\section{OBSERVATIONS:}

Statistical analysis of the data was carried out using Ecological Analysis Package - Biodiversity Pro. The data was properly arranged in the format required for the software function. The arrangement of data was made so that the rows indicated the species whereas the columns indicated the total number of individuals of a particular species in premonsoon, monsoon and post monsoon seasons. Alpha and beta diversity analysis in relation to seasonal variation in 
occurrence of butterflies was done using Biodiversity Pro (V2).

\section{RESULTS:}

During the study, seventyone species of Butterflies belonging to five families were recorded in Maval Tahsil (Table:1). Out of twentyseven species, six belong to Papilionidae, three to Pieridae, Ten to Nymphalidae, three to Lycaenidae and three to Hesperiidae. Species belonging to family Nymphalidae, were the most dominant $(40 \%)$ followed by Lycaenidae Hesperiidae, Pieridae, and Papilionidae. The status recording was as follows: VC- very common (75-100 sightings), C- common (50-75 sightings), NR- not rare (25-50 sightings), Rrare (5-25 sightings) and VR- very rare (1-5 sightings). Among the species fifteen were found very common, thirty-one species common, eighteen species not rare, six species were found rare and one species was observed in very rare category from study area. Ten species come under the protection of the Indian Wildlife (Protection) Act 1972. Out of the Twenty-seven species recorded are from botanical and nursery garden, forest area, from grassland, on plantation and from scrub biotope.

\section{DISCUSSION \& CONCLUSIONS:}

The species abundance increased from the beginning of monsoon, from the months June to July and reached a peak in the months from August to November. A decrease in species abundance was observed from the months December to January and continued up to the end of May, indicating the abundances of diverse species was positively affected by approaching warmer days, high relative humidity and more rainfall. These factors help to flourish diverse vegetations, which are vital food sources for many Butterfly species. Gutierrez \& Mendez (1995) reported that the abundance of Butterflies is not affected by altitudes but it is more related to the availability of food plants. Plants play vital role in increasing the Butterfly diversity and their abundance in the area. In study area, maximum species of Butterflies were recorded in forest biotope than followed by plantation, scrub, grassland and boticanal garden biotope. However, grassland and botanical garden are not observed as rich biotopes; heavy grazing pressure on grassland and use of pesticides in gardens has adversely affected diversity of Butterflies in these biotopes. Maval Tahsil, forest biotope is rich in butterfly diversity as observed in present study. The nectar flowering plants visited by Butterflies, as observed in our findings, namely Alstonia scholaris, Ageratum conyzoides, Nothapodytes nimmoniana, Carissa congesta, Asclepias curassavica, Calotropis gigantea, Senecio bombayensis, Zinnia eleganas, Cassia auriculata, Urena lobata, Pentas karmesiana, Gnidia glauca and Vitex negundo. Mulshi Tahsil is rich in floral diversity. The herbs from study area namely Celosia argentea and Tridax procumbens are more used by the Butterflies, probably due to long flowering period. The shrub Lantana camara is having flowering period throughout the year, so it is more used by Butterflies as their food plant. Number of Butterfly species also feed on other sources of food like tree sap, rotting fruits, rotting animals, animals dropping, minerals from wet soil and varying combinations of all these. Details of habitat used by Indian Butterflies are not known. Fresh information on the habitat and microhabitats of Butterflies will be very useful in all the regions of India (Kunte, 2000). Wildlife habitats are getting destroyed at an alarming rate with disastrous effects on biodiversity. While a large number of species have become extinct in the recent past, the survival of many others is threatened. Thus, habitat loss is considered as major threat to biodiversity of 
Butterflies. These findings will prove to have their own importance.

\section{REFERENCES:}

Rosenburg.

Kunte, K. (1997). Seasonal patterns in Butterfly abundance and species diversity in four tropical habitats in Northern Western Ghats. Journal of Bioscience 22(5): 593603.

Rane, N.S. \& S.P. Ranade (2004). Butterflies of Tamhini-Dongarwadi Area, Mulshi, Maharashtra. Zoos' Print Journal, 19(3): 1411-1413.
Padhye, A.D., N. Dahanukar, M. Paingankar, M. Deshpande \& D. Deshpande (2006). Season \& Landscape wise distribution of Butterflies in Tamhini, North-Western Ghats, India. Zoos' Print Journal 21(3): 2175-2181.

Chandrakar, M., S. Palekar and S. Chandrakar (2007). Butterfly fauna of Melghat region, Maharashtra. Zoos' Print Journal, 22 (7): 2762-2764.

www.wikipedia and Google maps

TABLE -1: List of Butterfly Species Observed from Study Area Mulashi

\begin{tabular}{|c|c|c|}
\hline Sr.No & Common Name & Scientific Name \\
\hline \multicolumn{3}{|c|}{ Suborder : Rhopalocera } \\
\hline \multicolumn{3}{|c|}{ I. Family: PAPILIONIDAE } \\
\hline \multicolumn{3}{|c|}{ 1. Subfamily: Papilioninae } \\
\hline 1 & Common Bluebottle & Graphium sarpedon Linnaeus \\
\hline 2 & Tailed Jay & $\begin{array}{l}\text { Graphium agamemnon } \\
\text { Linnaeus }\end{array}$ \\
\hline 3 & Common Mormon & Papilio polytes Linnaeus \\
\hline 4 & Lime Butterfly & Papilio demoleus Linnaeus \\
\hline 5 & Indian Sunbeam & Curetis thetis Drury \\
\hline \multicolumn{3}{|c|}{ 2. Subfamily: Polyommatinae } \\
\hline 6 & Dark Cerulean & Jamides bochus Cramer \\
\hline \multicolumn{3}{|c|}{ Suborder : Grypocera } \\
\hline \multicolumn{3}{|c|}{ II. Family: HESPERIIDAE } \\
\hline \multicolumn{3}{|c|}{ 1. Subfamily: Coeliadinae } \\
\hline 7 & Common Banded Awl & Hasora Chromus Cramer \\
\hline \multicolumn{3}{|c|}{ 2. Subfamily: Pyrginae } \\
\hline 8 & Tricoloured Pied Flat & Coladenia Indrani Moore \\
\hline 9 & Indian Palm Bob & Suastus gremius Fabricius \\
\hline \multicolumn{3}{|c|}{ III. Family: PIERIDAE } \\
\hline \multicolumn{3}{|c|}{ 1. Subfamily: Coliadinae } \\
\hline 10 & Small Grass Yellow & Eurema brigitta Cramer \\
\hline 11 & Common Grass Yellow & Eurema hecabe Linnaeus \\
\hline \multicolumn{3}{|c|}{ 2. Subfamily: Pierinae } \\
\hline 12 & Common Wanderer & Pareronia valeria Carmer \\
\hline
\end{tabular}




\begin{tabular}{|c|c|c|}
\hline \multicolumn{3}{|c|}{ 1. Subfamily: Danainae } \\
\hline 13 & Blue Tiger & Tirumala limniace Cramer \\
\hline \multicolumn{3}{|c|}{ 2. Subfamily: Charaxinae } \\
\hline 14 & Common Nawab & Polyura athamas Drury \\
\hline \multicolumn{3}{|c|}{ 3. Subfamily: Satyrinae } \\
\hline 15 & Common Evening Brown & Melanitis leda Linnaeus \\
\hline \multicolumn{3}{|c|}{ 4. Subfamily: Heliconiinae } \\
\hline 16 & Tawny Coster & Acraea violae Fabricius \\
\hline \multicolumn{3}{|c|}{ 5. Subfamily: Limenitinae } \\
\hline 17 & Chestnut Streaked Sailer & Neptis jumbah Moore \\
\hline 18 & Commom Sailer & Neptis hylas Linnaeus \\
\hline \multicolumn{3}{|c|}{ 6. Subfamily: Cyrestinae } \\
\hline 24 & Common Map & Cyrestis thyodamas Boisduval \\
\hline \multicolumn{3}{|c|}{ 7. Subfamily: Biblidinae } \\
\hline 19 & Angled Castor & Ariadne ariadne Linnaeus \\
\hline \multicolumn{3}{|c|}{ 8. Subfamily: Apaturinae } \\
\hline 20 & Black Prince & Rohana parisatis Westwood \\
\hline \multicolumn{3}{|c|}{ 9. Subfamily: Nymphalinae } \\
\hline 21 & Blue Pansy & Junonia orithiya Linnaeus \\
\hline \multicolumn{3}{|c|}{ V. Family: LYCAENIDAE } \\
\hline \multicolumn{3}{|c|}{ 1. Subfamily: Curetinae } \\
\hline 22 & Indian Sunbeam & Curetis thetis Drury \\
\hline \multicolumn{3}{|c|}{ 2. Subfamily: Polyommatinae } \\
\hline 23 & Banded Blue Pierrot & Discolampa ethion Westwood \\
\hline 24 & Zebra Blue & Leptotes plinius Fabricius \\
\hline \multicolumn{3}{|c|}{ VI. Family: HESPERIIDAE } \\
\hline \multicolumn{3}{|c|}{ 1. Subfamily: Coeliadinae } \\
\hline 25 & Common Banded Awl & Hasora Chromus Cramer \\
\hline \multicolumn{3}{|c|}{ 2. Subfamily: Pyrginae } \\
\hline 26 & Tricoloured Pied Flat & Coladenia Indrani Moore \\
\hline 27 & Indian Palm Bob & Suastus gremius Fabricius \\
\hline
\end{tabular}

